Piotr Grzebyk

\title{
Zatrudnianie pracowników w placówkach państw obcych na terenie Polski - zagadnienie immunitetu jurysdykcyjnego w sprawach cywilnych
}

\section{Wstęp}

Można bronić poglądu, że stosunki pracy mają szczególne znaczenie $\mathrm{w}$ procesie kształtowania się reguł immunitetu jurysdykcyjnego w prawie międzynarodowym. Sprawy pracownicze stanowią bowiem pokaźną grupę spraw cywilnych, w których występuje kwestia immunitetu państwa lub jego przedstawicieli. W Polsce zagadnienie to dotyczy przede wszystkim zatrudniania pracowników w placówkach państw obcych na terytorium RP. W literaturze było ono przedmiotem zainteresowania głównie nauki prawa międzynarodowego publicznego i prawa procesowego ${ }^{1}$. Uwzględnienie ,,perspektywy” prawa pracy

${ }^{1}$ Zob. przede wszystkim J. Ciszewski, Glosa do postanowienia Sądu Najwyższego z 18 marca 1998 r., Palestra 1999, nr 9-10, s. 202; J. Skrzydło, Glosa od postanowienia SN z 18 marca 1998 r., I PKN 26/98, PiP 1999, nr 10, s. 108; J. Ciszewski, Glosa do postanowienia Sadu Najwyższego z 11 stycznia 2000 r., I PKN 562/99, OSP 2000, nr 11, poz. 175, s. 581 oraz odpowiednie części następujących opracowań: J. Sutor, Immunitet dyplomatyczny i immunitet państwa, PS 2008, nr 4, s. 81 i nast.; K. J. Gruszczyński, Immunitet jurysdykcyjny państwa w orzecznictwie sądów krajowych $i$ międzynarodowych, Zeszyty Naukowe Zakladu Europeistyki Wyższej Szkoły Informatyki i Zarządzania w Rzeszowie 2009, nr 1, s. 57 i nast.; J. Ciszewski, Immunitet jurysdykcyjny państw obcych, SM 2000, nr 1-2, s. 123 i nast.; A. Wyrozumska, Polskie sady wobec immunitetu państwa obcego, PiP 2000, nr 3, s. 24; J. Sutor, Kwestia immunitetu państwa w kontekście Konwencji ONZ z 2004 r. o immunitetach jurysdykcyjnych państw i ich własności, [w:] B. Mikołajczyk, J. Nowakowska-Małusecka (red.), Prawo międzynarodowe, europejskie i krajowe - granice i wspólne 
może uzupełnić dyskusję nad kształtem immunitetu jurysdykcyjnego wynikającego z prawa międzynarodowego.

Opracowanie koncentruje się na trzech wybranych orzeczeniach Izby Pracy Sądu Najwyższego, które dotyczą immunitetu jurysdykcyjnego pracodawcy. W opinii autora ogniskuje się w nich kilka kwestii o charakterze podstawowym.

\section{Orzecznictwo Sądu Najwyższego}

W tezie uchwały z 26 września 1990 r., III PZP 9/90² Sąd Najwyższy stwierdził, że Centrum Techniki Samochodowej, jako komórka organizacyjna Przedstawicielstwa Handlowego Ambasady ZSRR w Rzeczypospolitej Polskiej, nie podlega jurysdykcji sądów polskich. W sprawie powodowie - pracownicy - wytoczyli powództwo przeciwko wspomnianej komórce, wskazując ją jako pracodawcę. W opinii Sądu Najwyższego w istocie pozwano przedstawicielstwo dyplomatyczne obcego państwa korzystające z immunitetu od jurysdykcji (cywilnej, administracyjnej) państwa przyjmującego. Sąd uznał w ten sposób, że pracodawcą jest ambasada ZSRR, choć wprost tego nie stwierdził. W uzasadnieniu nie do końca precyzyjnie określono pozycję procesową pozwanego. Z jednej strony, Sąd Najwyższy uznał, że „Centrum jako jednostka organizacyjna Przedstawicielstwa Handlowego ZSRR nie miało jurysdykcji krajowej (chodziło zapewne o zdolność sądową - przyp. P. G.) w rozumieniu art. $64 \S 1$ k.p.c. i nie mogło występować w tej sprawie jako strona pozwana", natomiast z drugiej strony, przemilczano kwestię zdolności sądowej ambasady, którą uznano za pozwanego pracodawcę. W dalszej części uzasadnienia wskazano, że wyłączenie przedstawicielstwa dyplomatycznego z jurysdykcji sądów polskich wynika z suwerenności państwa wysyłającego. Istnieje bowiem oczywisty i niezaprzeczalny związek między immunitetem jurysdykcyjnym państwa a przywilejami i immunitetami jego organów. Immunitet państwa powiązano więc wprost z art. 31 Konwencji wiedeńskiej o stosunkach dyplomatycznych z 1961 r., który traktuje przecież jedynie o immunitecie jurysdykcyjnym przedstawiciela dyplomatycznego. Z uchwały wynika również, że przyjęto koncepcję immunitetu absolutnego, przez co rozumie się możliwość powoływania się na niego niezależnie od rodzaju podejmowanej przez państwo działalności³

\footnotetext{
obszary, Katowice 2009, s. 557 i nast. W polskiej literaturze prawa pracy stosunkowo mało uwagi poświęcono zagadnieniu stosunków pracy w placówkach obcych państw na terenie Polski. Właściwie wszelkie uwagi w tym zakresie prezentowane są przy okazji komentarzy do art. 6 k.p., który dotyczy prawa właściwego. Zob. przykładowo K. Rączka w: Kodeks pracy. Komentarz, Warszawa 2010, s. 31; W. Muszalski, Kodeks pracy. Komentarz, Warszawa 2005, s. 17; E. Chmielek-Łubińska w: B. Wagner (red.) Kodeks pracy. Komentarz, Warszawa 2009, s. 29.

2 OSNC 1991, nr 2-3, poz. 17.

${ }^{3}$ W. Czapliński, A. Wyrozumska, Prawo międzynarodowe publiczne. Zagadnienia systemowe, Warszawa 2004, s. 236, M. N. Shaw, Prawo międzynarodowe, Warszawa 2000, s. 377 i nast.
} 
Podobne tezy i sposób argumentacji zaprezentowano w postanowieniu Sądu Najwyższego z 18 marca 1998 r., I PKN 26/98, gdzie stwierdzono, że korzystanie przez przedstawiciela dyplomatycznego z immunitetu od jurysdykcji cywilnej i administracyjnej państwa przyjmującego obejmuje także placówkę dyplomatyczną, będącą pracodawcą. W sprawie powódka domagała się uznania wypowiedzenia umowy o pracę dokonanego przez pozwany Konsulat Generalny Republiki Federalnej Niemiec w Krakowie za bezskuteczne. Sąd Najwyższy w pierwszej kolejności rozstrzygnął, kto był pracodawcą powódki w rozumieniu prawa materialnego. W uzasadnieniu czytamy, że „nie jest trafny pogląd wnoszącego kasację, że pracodawcą powódki nie był Konsul Generalny Republiki Federalnej Niemiec w Krakowie, lecz biuro administracyjne Konsulatu. W szczególności stwierdzenie, że Konsul podpisał z powódką umowę o pracę, nawiązując stosunek pracy $z$ biurem administracyjnym Konsulatu jest dowolne i nie poparte żadną argumentacją tym bardziej, że z umowy o pracę wynika niezbicie, że pracodawcą powódki jest Konsul Generalny Republiki Federalnej Niemiec w Krakowie, a tylko zakres obowiązków powódki obejmował, zgodnie z § 2 umowy o pracę ,,wszystkie czynności w dziale wizowym placówki”. Sąd uznał więc, inaczej niż w uchwale z 26 września 1990 r., że pracodawcą nie jest urząd obcego państwa (ewentualnie obce państwo), lecz urzędnik państwowy - konsul ${ }^{4}$. Wydaje się, że takie stanowisko, gdy chodzi o logikę wywodu, uzasadniało stwierdzenie, iż pozew skierowany przeciwko konsulowi nie powinien być rozpoznany z racji immunitetu konsularnego (art. 43 Konwencji o stosunkach konsularnych z 1963 r. ${ }^{5}$ ). Sąd Najwyższy w tym postanowieniu, bardziej kategorycznie niż w uchwale z 26 września 1990 r., powiązał kwestię właściwości sądów polskich do rozpoznawania spraw pracowniczych przeciwko obcemu państwu z kategorią immunitetu jurysdykcyjnego konsula. Charakterystyczny jest tu pogląd Sądu: „nawet gdyby uznać, że pracodawcą powódki było biuro administracyjne Konsulatu Generalnego Republiki Federalnej Niemiec w K., to brak jest podstaw do uznania, jak twierdzi powódka, że biuro to nie korzysta $\mathrm{z}$ immunitetu konsularnego od jurysdykcji sądów polskich". W mojej opinii, powyższy cytat świadczy o tym, że w postanowieniu Sądu Najwyższego z 18 marca 1998 r., I PKN 26/98 zaprezentowano stanowisko nie tylko, że immunitet konsularny rozciąga się na biuro konsularne, lecz, co bardziej znaczące, że z immunitetu konsularnego (dyplomatycznego) wynikać może immunitet państwa obcego ${ }^{6}$. Ponieważ za pracodawcę uznano osobę fizyczną, w praktyce nie było potrzeby badania zdolności sądowej pozwanego.

${ }^{4}$ Takie stanowisko jest w pewnym zakresie niezrozumiałe w kontekście „tezy” opublikowanej w OSNP 1999, nr 5, poz. 172, gdzie twierdzi się przecież, że to placówka jest pracodawcą „,...) placówkę dyplomatyczną, będącą pracodawcą".

${ }^{5} \mathrm{~W}$ uzasadnieniu błędnie jednak wskazywano na art. 31 Konwencji o stosunkach dyplomatycznych z $1961 \mathrm{r}$.

${ }_{6}$ Takie pomieszanie pojęć trafnie spotkało się krytyką. Zob. np. J. Ciszewski, Glosa do postanowienia Sąu Najwyższego z 18 marca 1998 r., Palestra 1999, nr 9-10, s. 207. 
Kolejnym orzeczeniem jest postanowienie Sądu Najwyższego z 11 stycznia 2000 r., I PKN 562/997 , w którym stwierdzono, że polskim sądom pracy przysługuje jurysdykcja krajowa w sprawie z powództwa obywatela polskiego przeciwko ambasadzie państwa obcego o uznanie bezskuteczności wypowiedzenia umowy o pracę (przywrócenie do pracy). W sprawie powód wniósł przeciwko ambasadzie obcego państwa w Warszawie pozew o uznanie bezskuteczności wypowiedzenia umowy o pracę. Sąd Najwyższy przyjął przede wszystkim, że pracodawcą powoda była ambasada. Jednocześnie pozwanie ambasady potraktowano jako pozwanie państwa, skoro w dalszej części uzasadnienia odnoszono się do immunitetu państwa obcego. Przyjęto, choć nie wprost, że pozwana ambasada ma zdolność sądową. Sąd Najwyższy podkreślił, że kodeks postępowania cywilnego nie reguluje immunitetu jurysdykcyjnego państwa oraz że immunitet ten dotyczyć może tylko działań państwa w wykonaniu aktów władzy publicznej (acta de iure imperii), a nie działań w zakresie obrotu cywilnoprawnego (handlowego) (acta de iure gestionis). Ambasada z kolei, występując w sprawie jako pracodawca, uczestniczy w obrocie cywilnoprawnym. W ten sposób uznano, że w tym przypadku nie ma możliwości powołania się na immunitet jurysdykcyjny państwa. Opowiedziano się w ten sposób za tzw. ograniczonym immunitetem państwa ${ }^{8}$. W nawiązaniu do wcześniejszego postanowienia Sądu Najwyższego z 18 marca 1998 r. podkreślono, że nie ma podstaw do przyjęcia, iż na ambasadę rozciąga się immunitet dyplomatyczny ambasadora jako przedstawiciela dyplomatycznego.

$\mathrm{Na}$ tle powyższych orzeczeń pojawiają się cztery zasadnicze kwestie wymagające rozstrzygnięcia: po pierwsze, kto jest pozwanym; po drugie, czy pozwanego można uznać w świetle prawa właściwego jako pracodawcę osób świadczących pracę na rzecz placówki państwa wysyłającego; po trzecie czy pozwanemu przysługuje immunitet i jaki jest jego rodzaj i wreszcie po czwarte, czy pozwany posiada zdolność sądową.

\section{Prawidłowe wskazanie pozwanego}

Należy pamiętać, że w procesie cywilnym pozwanym jest podmiot, który w pozwie został wskazany jako ten, przeciwko któremu kieruje się roszczenie. Jego prawidłowe określenie ma znaczenie przede wszystkim w kontekście prawa materialnego, którego reguły określą, czy dochodzone roszczenie jest zasadne i może być wyegzekwowane od wskazanego w pozwie i orzeczeniu podmiotu. Przypomnieć również należy, że to pozwanemu może ewentualnie przysługiwać

\footnotetext{
7 OSP 2000, nr 11, poz. 175.

${ }^{8}$ W. Czapliński, A. Wyrozumska, op. cit, s. 237; M. N. Shaw, op. cit., s. 379 i nast.
} 
immunitet i sąd zobowiązany jest badać, czy zachodzi wyjątek od właściwości sądowej (jurysdykcyjnej) państwa ${ }^{9} \mathrm{w}$ stosunku do wskazanej w pozwie strony ${ }^{10}$.

W stanie faktycznym rozstrzyganym w uchwale z 26 września 1990 r. pozwano komórkę organizacyjną przedstawicielstwa handlowego, co Sąd Najwyższy potraktował jako pozwanie przedstawicielstwa obcego państwa. W przypadku postanowienia z 18 marca 1998 r. pracownica pozwała konsulat, a w orzeczeniu $\mathrm{w}$ istocie stwierdzono, że pozwanym jest konsul ${ }^{11}$. Wreszcie w stanie faktycznym, który był podstawą dla postanowienia z 11 stycznia $2000 \mathrm{r}$. pozwano ambasadę, co nie przeszkodziło w uznaniu, że właściwie to pozwanym jest państwo obce ${ }^{12}$.

Uchwałę z 1990 r. i postanowienie z 2000 r. można traktować jako próbę uwzględnienia postulatu, że w przypadku podmiotów o złożonej strukturze (tak ma być w przypadku ,strony państwowej”) możliwe jest, aby jako pozwanego sąd oznaczył państwo obce, gdy uwzględniając wszelkie okoliczności sprawy, uda się ustalić, że powód w istocie od początku postępowania zamierzał dochodzić roszczeń od państwa, a wskazanie jako pozwanego ambasady wynikało z braku rozeznania w strukturze pozwanego ${ }^{13}$. Natomiast w postanowieniu z 1998 r. Sąd w swobodny sposób zmienił oznaczenie strony postępowania ${ }^{14}$.

Można się zgodzić z poglądem, że wskazanie w pozwie misji dyplomatycznej stanowi w istocie wytoczenie powództwa przeciwko obcemu państwu ${ }^{15}$. Trzeba jednak pamiętać, że takie rozwiązanie jest odstępstwem od reguły w polskim

9 P. Grzegorczyk, Reżim procesowy immunitetu państwa w postępowaniu cywilnym, PS 2010, nr 1, s. 23.

${ }^{10}$ Wydaje się, że nie zauważa tego J. Sutor, Immunitet dyplomatyczny $i$ immunitet państwa, PS 2008, nr 4, s. 93.

${ }^{11}$ Nie stwierdzono tego wprost, wskazuje na to uzasadnienie. Gdyby badać sprawę tak jak wskazano w pozwie, należało rozpoznać sprawę w określonych granicach podmiotowych i badać ewentualnie istnienie ,immunitetu konsulatu”.

${ }^{12}$ Nie stwierdzono tego wprost, wskazuje na to uzasadnienie. Gdyby badać sprawę tak jak wskazano w pozwie, należało rozpoznać sprawę w określonych granicach podmiotowych i badać ewentualnie istnienie ,immunitetu ambasady”.

${ }_{13}^{13}$ P. Grzegorczyk, op. cit., s. 506 i orzecznictwo w przypisie 1659.

14 Podobnie J. Ciszewski, Glosa do postanowienia Sądu Najwyższego z 18 marca 1998 r., Palestra 1999, nr 9-10, s. 203.

15 Zob. zwłaszcza postanowienie Sądu Rejonowego dla Warszawy Pragi z 2 października 1997, VIII P 727/97, cyt. za A. Wyrozumska, op. cit., s. 34, 36-37; P. Grzegorczyk, op. cit., s. 500. Taki pogląd dodatkowo można oprzeć na treści art. 2 ust. 1 lit. b konwencji Narodów Zjednoczonych o immunitetach jurysdykcyjnych państw i ich własności z 2004 r., który definiuje pojęcie państwa dla potrzeb stosowania tej umowy. United Nations Convention on Jurisdictional Immunities of States and Their Property, http://untreaty.un.org/ilc/texts/ instruments/english/conventions/4_1_2004. pdf (20.09.2010). Wydaje się odmiennie J. Sutor, Immunitet dyplomatyczny i immunitet państwa, PS 2008, nr 4, s. 92. Wskazana konwencja nie weszła jeszcze w życie. Zob. na temat konwencji np. J. Sutor, Kwestia immunitetu państwa w kontekście Konwencji ONZ z 2004 r. o immunitetach jurysdykcyjnych państw i ich własności, [w:] Prawo międzynarodowe, europejskie i krajowe - granice $i$ wspólne obszary, Katowice 2009, s. 557 i nast.; J. Ciszewski w: T. Ereciński (red.), Kodeks postepowania cywilnego. Komentarz, T. 5, Warszawa 2010, s. 273. 
prawie, według której, nawet istnienie tzw. pracodawcy wewnętrznego lub złożonego nie zwalnia pracownika z prawidłowego oznaczenia strony postępowania ${ }^{16}$. Co jednak bardziej istotne, pogląd ten nie wyjaśnia, w jakim zakresie podobną „zmianę” podmiotu postępowania można zastosować w przypadku pozwania konsula lub przedstawiciela dyplomatycznego państwa obcego. Często bowiem zdarza się, że pozew kierowany jest nie przeciwko państwu, ale przeciw samemu funkcjonariuszowi (the particular officer), który zawierał umowę (uczestniczył w jej zawieraniu) ${ }^{17}$.

Konkludując, należy stwierdzić, że to powód decyduje przeciwko komu toczy się postępowanie. Sąd rozpoznaje sprawę w tych granicach podmiotowych. Praktyka wskazuje, że w przypadku pracowników wykonujących pracę na rzecz misji w Polsce pozwanym będzie najczęściej przedstawiciel państwa (ambasador, konsul) albo jego organ (ambasada, konsulat), co w tym drugim przypadku, jeśli okoliczności sprawy na to pozwalają, należy traktować jako pozwanie państwa obcego.

\section{Pracodawca osób świadczących pracę na rzecz placówki - państwo, jego organ czy przedstawiciel?}

Prawidłowe określenie pozwanego pozostaje w ścisłym związku przede wszystkim z relacjami materialnoprawnymi. Jeśli pozwie się podmiot, który nie korzysta z immunitetu, ale nie jest pracodawcą, to sądy polskie sprawę rozpoznają, ale pozew oddalą. $Z$ kolei pozwanie podmiotu, któremu prawo materialne nakazuje spełnić świadczenie ze stosunku pracy, może być ograniczone przez przysługujący immunitet. Konieczna jest więc odpowiedź na pytanie, kogo pracownik świadczący pracę na rzecz misji powinien pozwać. Innymi słowy, jaki podmiot może być $\mathrm{w}$ świetle prawa właściwego uznany za pracodawcę i zobligowany orzeczeniem do spełnienia świadczenia.

Analizowane trzy orzeczenia sugerują, że pracodawcą osób świadczących pracę na rzecz placówek innych państw w Polsce może być organ państwa (np. am-

${ }^{16}$ Zob. przykładowo wyroki SN z 2 grudnia 2009 r. I PK 109/09, niepubl. i z 7 kwietnia 2010 r., II PK 287/09, niepubl.

17 ,it is now common practice to sue the ambassador as well as his sending state in a national court" E. Denza, Interaction between State and Diplomatic Immunity, s. 111, materiały z konferencji The Law and Politics of Foreign Sovereign Immunity z 10 kwietnia 2010 r., http://www.asil.org/ events/am08post/agendafull.html (20.09.2010). Zob. także R. Garnett, State immunity in employment matters, „International and Comparative Law Quarterly” 1997, s. 104; R. L. Garnett, The Perils of Working for a Foreign Government: Foreign Sovereign Immunity and Employment, „California Western International Law Journal" 1998, vol. 29, s. 170; J. Sutor, op. cit., s. 572. 
basada - uchwała z 26 września 1990 r., postanowienie z 11 stycznia 2000 r.) albo jego przedstawiciel (konsul - postanowienie z 18 marca 1998 r.). Co ciekawe, państwo nie pojawia się w tym przypadku jako pracodawca ${ }^{18}$.

\subsection{Autonomiczna definicja pracodawcy}

Do ustalenia pozostaje, jakie prawo jest właściwe dla określenia, kto jest pracodawcą. W sprawie, która nie wykazuje elementu międzynarodowego, ustalenie, jaki podmiot (jednostka) jest pracodawcą w rozumieniu prawa procesowego (art. 460 k.p.c.) zależy co do zasady od materialnego prawa pracy. W przypadku prawa polskiego jest to art. 3 k.p. ${ }^{19}$ Element obcy w danej sprawie nakazuje kilkuetapowe jej rozpoznanie. Po pierwsze, ustalić należy ewentualne wyłączenia władzy sądowej danego państwa (immunitety), po drugie, ustalić trzeba, czy W sprawie istnieje jurysdykcja krajowa (kwestie stricte procesowe), po trzecie, konieczne jest określenie prawa właściwego (zagadnienie kolizyjnoprawne) i po czwarte, można na podstawie prawa właściwego ocenić zasadność żądania. Dopiero na tym czwartym etapie możliwe jest stosowanie prawa polskiego również dla celów określenia podmiotu zatrudniającego.

Dopóki nie odpowie się na pytanie, czy sądy polskie mają kompetencję do rozstrzygania sprawy, nie można zastosować polskich norm kolizyjnych i prawa materialnego. Tym samym, na etapie ustalania władzy sądowej i jurysdykcji krajowej nie powinno się co do zasady stosować polskiego prawa materialnego (ewentualnie kolizyjnego) po to, aby ustalić, jaki podmiot jest pracodawcą w rozumieniu przepisów procesowych. Rozumienie pracodawcy na potrzeby przepisów międzynarodowego postępowania cywilnego, prawa prywatnego międzynarodowego i prawa pracy może być bowiem różne. Dobrym przykładem jest rozstrzygnięta przez Trybunał Sprawiedliwości Unii Europejskiej sprawa Glaxonsmithkline v. Rouard ${ }^{20}$, w której posłużono się pojęciem „współpracodawcy”

${ }^{18}$ Pogląd ten opiera się z pewnością na treści art. 6 k.p., który traktował o stosunku pracy pomiędzy pracownikiem a przedstawicielstwem, misją lub inną placówką państwa obcego lub instytucji międzynarodowej, działającymi na obszarze RP. Nie bez znaczenia było również, że w polskim prawie pracy państwo nie jest pracodawcą.

19 System polski wskazuje również, że pojęcia materialnoprawne mogą być modyfikowane przez regulacje procesowe. Art. $476 \S 5$ pkt 1 k.p.c. rozszerza bowiem podmiotowo pojęcia pracownika. Zastosowanie art. 3 k.p. w przypadku pracowników zatrudnionych w misjach obcych państw komplikuje dodatkowo określenie pracodawcy. Stosując wyłącznie art. 3 k.p., teoretycznie możliwe jest uznanie za pracodawcę nie państwa, lecz konsulatu albo ambasady. Taki zresztą pogląd reprezentowany jest w orzecznictwie Sądu Najwyższego - postanowienia z 11 stycznia 2000 r., I PKN 562/99, OSP 2000, nr 11, poz. 175.

${ }^{20}$ Wyrok z 22 maja 2008 r. w sprawie C-462/06 Glaxosmithkline i Laboratoires Glaxosmithkline v. Jean-Pierre Rouard, Zb. Orz. 2008, s. I-03965. 
na potrzeby prawa procesowego (art. 6 ust. 1 rozporządzenia 44/200121), co nie musi się koniecznie przekładać na traktowanie dwóch pozwanych podmiotów jako pracodawców w rozumieniu art. 3 k.p. TS UE nie stwierdził tego wprost, ale nie powinno budzić wątpliwości, że ze wskazanego orzeczenia wynika, iż na etapie ustalania władzy jurysdykcyjnej i jurysdykcji krajowej pojęcie „,pracodawcy” powinno podlegać wykładni autonomicznej22 na gruncie prawa europejskiego. Powyższej prawidłowości nie zaznaczono w uzasadnieniach postanowień Sądu Najwyższego z 18 marca 1998 r. i 11 stycznia 2000 r. i w glosach do tych orzeczeń. Wydaje się więc, że nieprecyzyjnie posługiwano się argumentacją odwołującą się do treści art. $6 \S 2$ k.p. ${ }^{23}$ Co więcej, przywiązanie wyłącznie do prawa polskiego doprowadziło do dyskusyjnego stwierdzenia, że pracodawcą jest ambasada (również urząd konsularny $)^{24}$.

Reguły wykładni autonomicznej wykluczają możliwość odwoływania się na potrzeby rozumienia interpretowanych pojęć wyłącznie do jednego systemu krajowego, w szczególności państwa forum. W przypadku pracowników placówek obcych państw wydaje się, że wykładnia autonomiczna w większym stopniu powinna odwoływać się do zwyczajów i umów międzynarodowych dotyczących placówek obcych państw i ich przedstawicieli. W tym kontekście należy wskazać, że w prawach krajowych regułą jest, aby osoby zatrudnione na rzecz placówek krajów wysyłających traktować jako zatrudnionych bezpośrednio przez państwo. Potwierdzają to regulacje międzynarodowe, które, gdy chodzi o wykonywanie pracy na rzecz misji, zakładają, że to państwo jest w takim przypadku zatrudniającym. Dotyczy to dwóch aktów. Pierwszym jest europejska konwencja o immunitecie państwa z 16 maja 1972 r. (European Convention on State Immuni$\left.t y^{25}\right)$, której art. 5. poświęcony jest szeroko rozumianej umowie o pracę ${ }^{26}$. Przepis,

${ }^{21}$ Rozporządzenia Rady (WE) nr 44/2001 z 22 grudnia 2000 r. w sprawie jurysdykcji i uznawania orzeczeń sądowych oraz ich wykonywania w sprawach cywilnych i handlowych. Tekst w jęz. polskim: Dz. Urz. UE, polskie wydanie specjalne z 2004 r., rozdz. 19, t. 4, s. 42; Dz. Urz. UE 2001, L 12, s. 1. Zob. obecnie Rozporządzenie Parlamentu Europejskiego i Rady (UE) nr 1215/2012 z dnia 12 grudnia 2012 r. w sprawie jurysdykcji i uznawania orzeczeń sądowych oraz ich wykonywania w sprawach cywilnych i handlowych. Dz. Urz. UE 2012, L 351, s.1.

${ }^{22} \mathrm{Na}$ temat autonomicznej wykładni w prawie wspólnotowym zob. np. A. Kalisz w: A. Wróbel (red.), Stosowanie prawa Unii Europejskiej przez sąd, Warszawa 2010, s. 330.

${ }^{23}$ Zob. J. Ciszewski, Glosa do postanowienia Sąu Najwyższego z 18 marca 1998 r., Palestra 1999, nr 9-10, s. 203.

${ }^{24}$ Mimo że z perspektywy prawa polskiego za pracodawcę teoretycznie można byłoby uznać urząd konsularny czy ambasadę (art. 3 k.p. przewiduje, że pracodawcą jest każda jednostka organizacyjna, choćby nie posiadała osobowości prawnej, jeżeli zatrudnia pracowników).

${ }^{25} \mathrm{http}: / /$ conventions.coe.int/Treaty/en/Treaties/Html/074.htm (20.09.2010). Konwencja obowiązuje w ośmiu państwach: w Austrii, Belgii, na Cyprze, w Niemczech, Luksemburgu, Holandii, Szwajcarii i Wielkiej Brytanii. Polska nie ratyfikowała tej umowy, http://conventions.coe.int/treaty/ Commun/ChercheSig. asp? $\mathrm{NT}=074 \& \mathrm{CM}=0 \& \mathrm{DF}=\& \mathrm{CL}=\mathrm{ENG}(20.09 .2010)$.

${ }^{26}$ Explanatory Report, pkt 30, http://conventions.coe.int/Treaty/EN/Reports/HTML/074.htm (20.09.2010). 
ustanawiając reguły powoływania się na immunitet państwa, wyraźnie stwierdza, że chodzi o postępowania dotyczące umowy o pracę pomiędzy państwem a osobą fizyczną (the proceedings relate to a contract of employment between the State and an individual). Drugim jest Konwencja Narodów Zjednoczonych o immunitetach jurysdykcyjnych państw i ich własności z 2004 r. Jej art. 11 podobnie jak art. 5 konwencji z Bazylei stanowi, że przepis znajduje zastosowanie w przypadku postępowań dotyczących umowy o pracę pomiędzy państwem a osobą fizyczną (a proceeding which relates to a contract of employment between the State and an individual).

Prawo międzynarodowe publiczne nie daje podstaw do twierdzenia, że pracodawcą (stroną umowy o pracę) może być ambasada, konsulat lub jakakolwiek misja państwa w innym kraju. Są to organy państwa wysyłającego, które nie mają osobowości w państwie przyjmującym i nie mogą stawać w jego sądach, a bezpośrednią odpowiedzialność za działania tych organów ponosi państwo wysyłają$\mathrm{ce}^{27}$. Zasady tej nie powinny zmieniać regulacje krajowe, w tym prawa polskiego, które nie przewiduje, aby pracodawcą był Skarb Państwa ${ }^{28}$.

\subsection{Znaczenie immunitetu dyplomatycznego i konsularnego}

W tym miejscu należy przeanalizować pogląd dopuszczający istnienie stosunku pracy z przedstawicielem obcego państwa ${ }^{29}$. Na podstawie postanowienia z 18 marca 1998 r., w którym pracodawcą miał być konsul, można dojść do wniosku, że w opinii Sądu Najwyższego, konsul, angażując do pracy pracownika, może występować w trzech wyłączających się rolach. Po pierwsze, jako osoba zupełnie prywatna (a contrario 43 ust. 1 konwencji o stosunkach konsularnych). Po drugie, jako podmiot wykonujący tzw. „,czynności urzędowe” ${ }^{30} \mathrm{~W}$ swoim imieniu, przez co należy rozumieć zawarcie stosunku pracy, którego stroną jest konsul jako osoba fizyczna. Po trzecie wreszcie, konsul występować może w roli podmiotu wykonującego czynności urzędowe w imieniu państwa, przez co w tym

27 J. Sutor, Prawo dyplomatyczne i konsularne, Warszawa 2003, s. 61; A. Wyrozumska, op. cit., s. 32, J. Sutor, Immunitet dyplomatyczny i immunitet państwa, PS 2008, nr 4, s. 84.

${ }^{28}$ G. Goździewicz, T. Zieliński w: L. Florek (red.), Kodeks pracy. Komentarz, Warszawa 2009, s. 40.

${ }^{29}$ W literaturze nie wyklucza się bowiem, aby przedstawiciel państwa (np. konsul lub ambasador) mógł być pracodawcą i w konsekwencji ewentualnym pozwanym. P. Grzegorczyk, Immunitet państwa w postępowaniu cywilnym, Warszawa, 2010, s. 60. Wydaje się, że dopuszcza to również J. Sutor, op. cit., s. 87, 88. Autorzy nie wskazują jednak, czy przedstawiciel państwa może być pracodawcą dla służby domowej czy również dla pracowników świadczących pracę na rzecz misji.

30 S. Sawicki, Przywileje i immunitety konsularne, Wrocław 1989, s. 132; S. Sawicki, Zakres czynności urzędowych objętych konsularnym immunitetem jurysdykcyjnym, Zeszyty Naukowe Akademii Spraw Wewnętrznych 1977, nr 16, s. 118. 
przypadku należy rozumieć zawarcie stosunku pracy w imieniu państwa. Konsul działa wówczas jedynie jako przedstawiciel pracodawcy (najlepiej jego rolę ukazuje w kontekście prawa polskiego art. $3^{1}$ k.p. $\left.{ }^{31}\right)$.

Powyższy podział, jak i wynikające z niego stanowisko, że funkcjonariusz państwa, któremu przysługuje immunitet jurysdykcyjny (konsularny albo dyplomatyczny), może być stroną umowy o pracę, są nieprecyzyjne. Głównym błędem w takim rozumowaniu jest rozstrzyganie o kompetencji do zawierania umów (np. bycia stroną stosunków zobowiązaniowych) na podstawie przyznanego uprawnienia o charakterze procesowym. Są to dwie choć funkcjonalnie ze sobą związane, jednak kategorialnie zupełnie odrębne kwestie. Nietrafny jest pogląd, że z przepisów dotyczących immunitetów w sprawach cywilnych z konwencji o stosunkach dyplomatycznych czy konsularnych wynika samoistnie kompetencja do zawierania umów o pracę we własnym imieniu ${ }^{32}$. Funkcjonariusz państwa działa w imieniu właściwego pracodawcy (państwa obcego) i nie jest stroną umowy o pracę osób świadczących pracę na rzecz misji ${ }^{33}$. Wprawdzie można podnosić, że sama konstrukcja immunitetu np. konsularnego wskazuje na to, że właśnie urzędnik lub pracownik konsularny jest stroną umowy (zob. w szczególności art. 43 ust. 2 lit a konwencji o stosunkach konsularnych). Podnosić można bowiem, że gdyby było inaczej, immunitet konsularny nie byłby w ogóle potrzebny ${ }^{34}$ - stroną wszystkich umów, jakie zawiera konsul w wykonywaniu swoich funkcji, byłoby reprezentowane przez niego państwo ${ }^{35}$. Jako kontrargument dla takiego stanowiska wystarczy podnieść, że funkcja immunitetu jurysdykcyjnego przedstawiciela obcego państwa realizuje się również w tym, aby nawet gdy powodowi, któremu wydawać się może, że ten właśnie przedstawiciel jest jego dłużnikiem, nie mógł go mocą jednostronnej decyzji procesowej uwikłać w postępowanie sądowe ${ }^{36}$.

Poglądu, że stroną stosunku pracy osób świadczących pracę na rzecz misji jest wyłącznie państwo nie zmienia również treść art. 1 lit. h konwencji o stosunkach dyplomatycznych (,,prywatny służący” oznacza osobę zatrudnioną w służ-

${ }^{31}$ Zob. J. Ciszewski, Glosa do postanowienia Sadu Najwyższego z 18 marca 1998 r., Palestra 1999, nr 9-10, s. 203.

${ }^{32}$ Choć z art. 31 ust. 1 lit a i b konwencji o stosunkach dyplomatycznych oraz art. 43 ust. 2 lit a konwencji o stosunkach konsularnych wynika, że twórcy umów zakładali, iż stroną niektórych stosunków prawnych jest przedstawiciel państwa.

33 J. Skrzydło, op. cit., s. 111.

${ }^{34}$ Do podobnego wniosku choć w innym kontekście dochodzi A. Wyrozumska, op. cit., s. 31.

35 „Odcinkami działalności konsula wyjętymi spod jurysdykcji państwa przyjmującego są wyłącznie tylko te, które są wypływem jego działalności jako organu państwa wysyłającego. Wykonanie bowiem jurysdykcji z ich powodu nad konsulem byłoby wykonywaniem jurysdykcji nie nad osobą konsula, ale nad państwem wysyłającym, które działa przez konsula jako przez swój organ i byłoby zatem oczywistym złamaniem zasady prawa narodów, głoszącej par in parem non habet iudicium. W. Namysłowski, System prawa konsularnego, Warszawa 1949, s. 142.

${ }^{36}$ Zob. trafnie J. Sutor, op. cit., s. 83. 
bie domowej członka misji, która nie jest pracownikiem państwa wysyłającego). $\mathrm{Z}$ przepisu tego można nawet, choć jedynie za pomocą argumentacji a contrario, wnioskować, że w innych niż wymieniona $\mathrm{w}$ art. 1 lit h sytuacjach pracownik związany jest stosunkiem pracy z państwem obcym, a nie jego przedstawicielem.

Poglądu powyższego nie zmieniają również uwagi przedstawione przy okazji komentarzy do art. 5. konwencji z 1972 r. (Explanatory Report). Stwierdzono tam że „W odniesieniu do umów o pracę z misjami dyplomatycznymi lub urzędami konsularnymi art. 32 powinien być wzięty pod uwagę" ${ }^{37}$. Art. 32 stanowi, że „żadne z postanowień niniejszej Konwencji nie będzie wywierało wpływu na przywileje i immunitety odnoszące się do wykonywania funkcji misji dyplomatycznych i urzędów konsularnych oraz związanych z nimi osób". W uzasadnieniu do cytowanego przepisu stwierdzono $z$ kolei, że przywileje i immunitety dyplomatyczne oraz konsularne zostały już uregulowane przez normy prawa międzynarodowego; w dwóch konwencjach wiedeńskich i umowach dwustronnych. Podstawy do ich regulowania były inne niż te leżące u podstaw konwencji bazylejskiej. W związku z tym, konwencja o immunitecie państw w żaden sposób nie może naruszać bezpośrednio ani pośrednio immunitetów dyplomatycznych i konsularnych. W przypadku kolizji konwencji bazylejskiej i wspomnianych umów dotyczących przywilejów i immunitetów przedstawicieli państw, te drugie powinny mieć pierwszeństwo ${ }^{38}$. Taką samą regułę „kolizyjną” zawiera art. 3 ust. 1 konwencji z 2004 r. Przepisy te, jak trafnie podniesiono w literaturze, należy interpretować jako dodatkową gwarancję immunitetu jurysdykcyjnego przysługującego osobom (a nie państwu) oraz gwarancję nienaruszalności mienia misjii ${ }^{39}$.

Konkludując, wydaje się, że w orzecznictwie Sądu Najwyższego aktualnym poglądem jest traktowanie organu albo przedstawiciela państwa obcego jako pracodawcy osób świadczących pracę w misji. Stanowisko to jest nieprecyzyjne. Za pracodawcę i w konsekwencji ewentualnego pozwanego powinno być uznane państwo obce, a nie jego organ działający za granicą. Wprawdzie powoduje to wątpliwości interpretacyjne związane $\mathrm{z}$ wynikającą z polskiego prawa pracy zasadą, że pracodawcą nie jest państwo lecz jego organy. Więcej korzyści płynie jednak z modyfikacji tej reguły i dopuszczenia, aby wyjątkowo państwo obce było stroną stosunku pracy. Przedstawiciel państwa będzie podmiotem samodzielnie zatrudniającym osoby fizyczne w przypadku służby domowej. Powoływanie się wyłącznie na prawo krajowe (kolizyjne i materialne) w celu określenia pracodawcy na etapie ustalania immunitetu nie jest poprawne.

${ }^{37}$ „As regards contracts of employment with diplomatic missions or consular posts, Article 32 shall also be taken into account". Explanatory Report, pkt 30, http://conventions.coe.int/Treaty/EN/ Reports/HTML/074. htm (20.09.2010).

${ }_{38}$ Explanatory Report, pkt 30, http://conventions.coe.int/Treaty/EN/Reports/HTML/074.htm (20.09.2010).

39 J. Skrzydło, op. cit., s. 112. 


\section{Immunitet państwa}

Należy określić, w jakim zakresie państwo może powoływać się na immunitet jurysdykcyjny przed sądami polskimi w sprawach pracowniczych. Punktem wyjścia jest przypomnienie, że immunitet jurysdykcyjny państwa obcego nie jest uregulowany $\mathrm{w}$ ustawodawstwie polskim ${ }^{40}$. Wydaje się, że również w orzecznictwie nie wypracowano jeszcze jednolitych reguł w tym przedmiocie, co odnosi się w szczególności do spraw dotyczących stosunków pracy osób wykonujących pracę na rzecz misji państw obcych w Polsce.

Sąd polski, przed który wniesiono pozew przeciwko pracodawcy - obcemu państwu - musi wydać rozstrzygnięcie. Może, najkrócej rzecz ujmując, orzec o odrzuceniu pozwu ze względu na brak władzy jurysdykcyjnej sądów polskich, kiedy stwierdzi immunitet państwa albo merytorycznie rozpoznać sprawę, gdy ustali brak immunitetu.

W celu ustalenia istnienia immunitetu sądy polskie nie mogą powoływać się na normy stanowione. Konieczne więc będzie powołanie się na normę prawa zwyczajowego (art. 9 Konstytucji) ${ }^{41}$. Z pewnością nie będzie to zadanie łatwe dla sądów niższych instancji.

W literaturze zagranicznej podnosi się, że analiza regulacji ustawowych i orzecznictwa państw obcych pozwala wyróżnić cztery metody, według których rozstrzyga się, czy w sporze dotyczącym umowy o pracę możliwe jest powoływanie się przez państwo na immunitet jurysdykcyjny ${ }^{42}$. Każda $\mathrm{z}$ tych metod jest rozwinięciem znanego podziału na czynności iure imperii i iure gestionis ${ }^{43}$. Bez wątpienia praktyka sądów obcych państw przyczynia się do tworzenia zwyczaju międzynarodowego w tym zakresie. Pierwsza metoda polega na ocenie kontekstu lub umiejscowienia stosunku pracy (context or location of the employment). Jako przykład podaje się zatrudnienie właśnie w ambasadzie, niezależnie od stanowiska i podejmowanych obowiązków. W takim przypadku, jakakolwiek ingerencja w działalność obcego państwa w postępowaniu sądowym naruszałaby jego suwerennośćc ${ }^{4}$. Druga metoda sprowadza się do ustalenia statusu i obowiązków pracownika. Odróżnia się więc pracowników, którzy wykonują funkcje ściśle

${ }^{40}$ J. Ciszewski, Immunitet jurysdykcyjny państw obcych, SM 2000, nr 1-2, s. 129.

${ }^{41}$ Za związaniem RP również zwyczajami międzynarodowymi jednoznacznie B. Banaszak, Konstytucja Rzeczpospolitej Polskiej. Komentarz, Warszawa 2009, s. 81; B. Banaszak, Prawo konstytucyjne, Warszawa 2001, s. 148; W. Skrzydło, S. Grabowska, S. Grabowski (red.), Konstytucja RP. Komentarz encyklopedyczny, Warszawa 2009, s. 757. Zob. jednak P. Winczorek, Komentarz do Konstytucji RP, Warszawa 2008, s. 34.

${ }^{42}$ R. L. Garnett, The Perils of Working for a Foreign Government: Foreign Sovereign Immunity and Employment, California Western International Law Journal 1998, vol. 29, s. 135 i nast.

${ }^{43}$ R. Garnett, State immunity in employment matters, ICLQ 1997, s. 83.

${ }^{44}$ R. L. Garnett, The Perils..., s. 135. Przykładowo sprawa Ferdman v. Consulate Gen. of Isr., No. 98 C 1555, 1998 WL 120230. 
związane z wykonywaniem władzy państwa od tych, których obowiązki można sprowadzić do czynności niezwiązanych z wykonywaniem władzy publicznej ${ }^{45}$, które to obowiązki nie różnią się co do zasady od tych podejmowanych przez pracowników w prywatnych przedsiębiorstwach ${ }^{46}$. Trzeci sposób odnosi się do ustalenia terytorialnego powiązania pracownika i umowy o pracę z państwem forum (territorial connection). W istocie chodzi jednak o minimalne terytorialne powiązanie skargi (claim) z państwem forum ${ }^{47}$. Wreszcie czwarta metoda dotyczy analizy samego powództwa wniesionego w sprawie i odpowiedzi na pytanie, czy środek ten nie spowoduje nadmiernego wkroczenia we władzę suwerennego państwa (isolation and characterization of the particular claim). Jako przykład sprawy, w której państwu przysługuje immunitet podaje się taką, w której konieczne dla oceny wniesionego przez pracownika środka są ustalenia dotyczące działań służb bezpieczeństwa państwa. Zastrzec należy, że wskazane metody wzajemnie nie wykluczają się i często uzupełniają się w orzecznictwie i ustawodawstwie krajowym $^{48}$.

$\mathrm{Na}$ kształtowanie polskiego orzecznictwa $\mathrm{w}$ sprawach pracowniczych, w których pozwanym jest państwo obce, mogą również pomocniczo mieć wpływ przepisy wskazanych wyżej konwencji; bazylejskiej z 1972 r. i Narodów Zjednoczonych z $2004 \mathrm{r}^{49}$ Wprawdzie Polska nie jest stroną tych umów ${ }^{50}$, jednak ich regulacje, o ile stanowią część zwyczajowego prawa międzynarodowego, są w stosunku do niej wiążące ${ }^{51}$. Można nawet stwierdzić, że przepisy tych konwencji dotyczące umów o pracę są rozwinięciem i doprecyzowaniem opisanych wyżej czterech metod. W tym kontekście na uwagę zasługuje w szczególności pogląd Europejskiego Trybunału Praw Człowieka w Strasburgu w sprawie Cudak

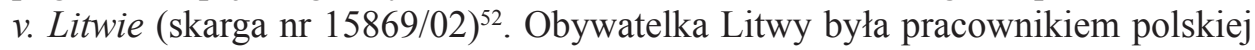
ambasady w Wilnie. Wykonywała prace sekretarskie. Była również operatorką centrali telefonicznej. Po rozwiązaniu umowy przez pracodawcę pozwała polskie państwo przed sąd litewski, domagając się odszkodowania za nieuzasadnione zwolnienie. Rząd polski podniósł, że w sprawie przysługuje mu immunitet jurysdykcyjny. Sądy litewskie, w tym Sąd Najwyższy uznały na tej podstawie brak swojej jurysdykcji w sprawie. Powódka wniosła sprawę do ETPCz, zarzucając

${ }^{45}$ W literaturze określa się je jako routine, purely ,, operational” duties. R. L. Garnett, op. cit., s. 135.

${ }^{46}$ Sprawa Holden v. Canadian Consulate, 92 F.3d $918\left(9^{\text {th }}\right.$ Cir. 1996).

${ }^{47}$ R. L. Garnett, op. cit., s. 135.

48 R. Garnett, State immunity..., s. 85.

49 Tak też J. Ciszewski, Glosa do postanowienia Sądu Najwyższego z 18 marca 1998 r., Palestra 1999, nr 9-10, s. 206. Odmiennie J. Sutor, op. cit., s. 94.

${ }^{50}$ Konwencja obowiązuje w ośmiu państwach: w Austrii, Belgii, na Cyprze, w Niemczech, Luksemburgu, Holandii, Szwajcarii i Wielkiej Brytanii, http://conventions.coe.int/treaty/Commun/ ChercheSig.asp?NT $=074 \& \mathrm{CM}=0 \& \mathrm{DF}=\& \mathrm{CL}=\mathrm{ENG}(20.09 .2010)$.

${ }^{51}$ Zob. A. Wyrozumska, op. cit., s. 40.

52 Omówienie sprawy np. w: EHRLR 2010, nr 4, s. 435-438. 
naruszenie art. 6 Konwencji o ochronie praw człowieka i podstawowych wolności. Trybunał podkreślił, że Litwa nie głosowała przeciwko Konwencji z 2004 r. Poza tym, powołując się na reguły prawa publicznego międzynarodowego, podkreślił, że nawet jeśli państwo nie ratyfikuje danej umowy, może ono być związane przez niektóre z jej postanowień, jeśli ich treść odzwierciedla zwyczajowe prawo międzynarodowe. Trybunał za taki przepis uznał właśnie art. 11 Konwencji z 2004 r. ${ }^{53}$ Przypomniano również, że już w sprawie Fogarty v. Wielkiej Brytanii (skarga nr 37112/97) ${ }^{54} \mathrm{r}$. zaznaczono, że w międzynarodowym i porównawczym prawie daje się zauważyć tendencję do ograniczania immunitetu państwa w sprawach ze stosunku pracy.

Artykuł 11 Konwencji z 2004 r. poświęcony jest umowie o pracę ${ }^{55}$. Przepis stanowi, że w sprawach dotyczących umów o pracę (proceeding which relates to a contract of employment), jeśli państwa inaczej nie postanowiły, państwo nie może powoływać się na immunitet jurysdykcyjny przed sądem innego państwa, który byłby właściwy do rozpoznania sprawy, jeżeli praca była lub miała być wykonana w całości lub części na terytorium państwa forum (art. 11 ust. 1 konwencji). Reguła ta nie obowiązuje w przypadku, gdy: a) pracownik został zatrudniony do wykonywania szczególnych funkcji w wykonywaniu rządowego urzędu ${ }^{56}$; b) pracownik jest: i) przedstawicielem dyplomatycznym w rozumieniu konwencji wiedeńskiej o stosunkach dyplomatycznych, ii) urzędnikiem konsularnym w rozumieniu konwencji wiedeńskiej o stosunkach konsularnych, iii) członkiem personelu dyplomatycznego misji stałej przy organizacji międzynarodowej lub misji specjalnej, lub jest zatrudniony do reprezentowania państwa na międzynarodowej konferencji, iv) jakąkolwiek inną osobą, której przysługuje immunitet dyplomatyczny; c) przedmiot postępowania dotyczy zatrudnienia, przedłużenia zatrudnie-

${ }^{53}$ Krytycznie w tym przedmiocie M. Balcerzak, M. Kałduński, Immunitet jurysdykcyjny państwa - glosa do wyroku ETPCZ z 23.03.2010 r. w sprawie Cudak v. Litwa, EPS2010, nr 11, s. 42.

${ }^{54} \mathrm{~W}$ sprawie pracownica była zatrudniona w ambasadzie USA w Londynie. W $1995 \mathrm{r}$. została zwolniona i pozwała pracodawcę przed sądem w Londynie, zarzucając dyskryminację ze względu na płeć. Ostatecznie przyznano jej odszkodowanie, jednak w trakcie postępowania została zatrudniona na jeden rok w innej jednostce ambasady. Po upływie tego okresu jej aplikacja na kolejne stanowisko została odrzucona. Pracownica wniosła przez sąd brytyjski pozew, ponownie zarzucając dyskryminację. Tym razem rząd USA podniósł, że państwu przysługuje immunitet. Trybunał w Strasburgu zaznaczył, że stosowanie doktryny immunitetu również w stosunkach pracy jest ograniczane. Mimo pewnych różnic w praktyce orzeczniczej państw, doktryna pełnego immunitetu państwa dotyczy jednak zatrudniania w ambasadzie. Ponadto podkreślono, że postępowanie w sprawie dotyczyło dyskryminacji w procesie rekrutacji, a nie zobowiązań z istniejącego stosunku pracy (contractual rights of a current employment). Szerzej zob. przykładowo omówienie tej sprawy przez M. Emberlanda w AJIL 2002, vol. 96, issue 3, s. 699 i nast.

${ }^{55}$ Zob. ogólnie w tym zakresie np. E. K. Bankas, The State Immunity Controversy in International Law: Private Suits Against Sovereign States in Domestic Courts, Heidelberg 2005, s. 307.

${ }^{56} \mathrm{~Np}$. prywatne sekretarki, thumacze. Zob. A. Watts, The International Law Commission 1949-1998, vol. III, Final Draft Articles and other Materials, Oxford 1999, s. 2064. 
nia lub przywrócenia do $\operatorname{pracy}^{57}$; d) przedmiot postępowania dotyczy zwolnienia lub zakończenia zatrudnienia, a w opinii określonego w przepisie organu państwa to postępowanie mogłoby naruszyć interesy bezpieczeństwa tego państwa; e) w chwili wszczęcia postępowania pracownik jest obywatelem zatrudniającego państwa, chyba że ma on miejsce zamieszkania w państwie forum; f) strony uzgodniły na piśmie inaczej, chyba że zgodnie z prawem państwa forum, sądom tego państwa przysługuje jurysdykcja wyłączna ${ }^{58}$.

Z kolei w Konwencji z 1972 r. umowie o pracę poświęcony jest art. 5. Zgodnie z nim państwo nie może powoływać się na immunitet, jeżeli postępowanie dotyczy umowy o pracę zawartej przez to państwo, jeżeli praca ma być wykonywana na terytorium państwa forum (art. 5 ust. 1 konwencji). Od tej zasady przewidziano kilka wyjątków. Nie stosuje się jej, gdy: a) pracownik w chwili wszczęcia postępowania ma obywatelstwo zatrudniającego państwa; b) w chwili zawierania umowy pracownik nie miał obywatelstwa państwa forum ani nie miał tam miejsca zamieszkania; c) strony na piśmie postanowiły inaczej, chyba że zgodnie z prawem państwa forum, sądy tego państwa mają w sprawie wyłączną jurysdykcję (art. 5 ust. 2 konwencji $)^{59}$. W uzasadnieniu do konwencji wyjaśniono ogólnie, że wyodrębnienie umowy o pracę od innych umów (zob. art. 4 Konwencji z 1972 r.) wynika z tego, iż w niektórych przypadkach usprawiedliwione jest przyznanie pozwanemu państwu immunitetu. W szczególności dotyczyć to ma sytuacji opisanych w punktach a-c. W tych bowiem przypadkach powiązania pomiędzy pracownikiem i zatrudniającym państwem są co do zasady bliższe niż te pomiędzy pracownikiem i państwem forum ${ }^{60}$. W konwencji tej przyjęto więc także regułę, zgodnie z którą powoływanie się przez państwo na swój immunitet w stosunkach pracy nie jest uzasadnione.

Ponadto, nawet uznając wątpliwości dotyczące charakteru art. 11 konwencji z 2004 r. ${ }^{61}$ i art. 5 konwencji bazylejskiej, można zasadnie twierdzić, że przepisy te potwierdzają tendencje do ograniczania immunitetu państwa w sprawach pracowniczych. Okoliczność ta stanowi poważny argument za tym, aby w tym samym kierunku rozwijać polską praktykę orzeczniczą ${ }^{62}$, przez co sądy polskie współuczestniczyłyby w tworzeniu prawa zwyczajowego ${ }^{63}$.

\footnotetext{
${ }^{57}$ Co nie dotyczy dochodzenia samego odszkodowania w wymienionych typach spraw pracowniczych. Tak A. Watts, op. cit., s. 2066.

${ }^{58}$ Tłumaczenie własne. Podobnie przetłumaczył J. Ciszewski w: T. Ereciński (red.), Kodeks postepowania cywilnego. Komentarz, T. 5, Warszawa 2010, s. 274.

${ }_{59}$ Poza zakresem niniejszego opracowania pozostaje art. 5 ust. 3 konwencji.

${ }^{60}$ Explanatory Report, pkt 30, http://conventions.coe.int/Treaty/EN/Reports/HTML/074.htm (20.09.2010).

${ }^{61}$ M. Balcerzak, M. Kałduński, op. cit., s. 42.

62 Podobnie J. Ciszewski, Glosa do postanowienia Sadu Najwyższego z 18 marca 1998 r., Palestra 1999, nr 9-10, s. 206.

${ }^{63}$ A. Wyrozumska, op. cit., s. 41, przypis 50.
} 
Konkludując, art. 11 Konwencji z 2004 r. oraz art. 5 konwencji bazylejskiej powinny być pomocniczo stosowane przez sądy polskie w celu ustalenia immunitetu państwa obcego. Nawet przy braku akceptacji poglądu, że wskazane przepisy odzwierciedlają zwyczaj międzynarodowy, reguły z nich wynikające powinny stanowić pomocniczą podstawę orzekania przez sądy polskie.

\section{Zdolność sądowa pracodawcy}

Na zakończenie należy poczynić uwagę na temat zdolności sądowej pracodawcy pracowników świadczących pracę na rzecz misji, od której zależy skuteczne pozwanie przed sądami polskimi podmiotu zatrudniającego ${ }^{64}$. W analizowanych trzech orzeczeniach Sądu Najwyższego zagadnienie to nie było szerzej omawiane $^{65}$, choć przyjęcie, że pozwanym jest właśnie misja państwa, wymagałoby podjęcia tej kwestii. Wydaje się, że Sąd Najwyższy przyjął po prostu, że misji przysługuje zdolność sądowa na podstawie art. 460 k.p.c. Jeśli jednak uzna się, że pracodawcą jest państwo, a nie ambasada (konsulat), to zagadnienie zdolności sądowej nie rodzi wątpliwości w stosowaniu prawa, ponieważ państwo obce jako zagraniczna osoba prawna wyposażona jest w zdolność sądową i działa $\mathrm{w}$ postępowaniu cywilnym przez swoje organy ${ }^{66}$. Jest to dodatkowy argument potwierdzający trafność poglądu, że pracodawcą pracowników świadczących pracę na rzecz misji jest państwo, a nie urząd (konsulat, ambasada).

\section{Wnioski}

Poniżej znajdują się najważniejsze wnioski z niniejszego opracowania:

1. Powód decyduje, przeciwko komu toczy się postępowanie. Sąd rozpoznaje sprawę w tych granicach podmiotowych. Praktyka wskazuje, że w przypadku pracowników wykonujących pracę na rzecz misji w Polsce pozwanym będzie

${ }^{64} \mathrm{Na}$ uwagę zasługuje orzeczenie sądu czeskiego, który uznał, że ambasada nie jest osobą fizyczną ani prawną i nie ma zdolności prawnej do przystąpienia do sprawy. Sprawa cytowana przez K. J. Gruszczyński, op. cit., s. 62, przypis 5.

${ }^{65}$ Zob. jednak postanowienie Sądu Najwyższego z 25 maja 2007 r., I CSK 6/07, OSNC 2008, nr 7-8, poz. 90, gdzie stwierdzono, że ambasada państwa obcego w Polsce nie ma zdolności sądowej.

${ }^{66}$ Zob. postanowienie Sądu Najwyższego z 25 maja 2007 r., I CSK 6/07, OSNC 2008, nr 7-8, poz. 90, P. Grzegorczyk, op. cit., s. 495. 
najczęściej przedstawiciel państwa (ambasador, konsul) albo jego organ (ambasada, konsulat), co w tym drugim przypadku, jeśli okoliczności sprawy na to pozwalają, należy traktować jako pozwanie państwa obcego.

2. Z orzeczeń Sądu Najwyższego wynika, że pracodawcą osób świadczących pracę na rzecz placówek innych państw w Polsce może być organ państwa albo jego przedstawiciel.

3. W przypadku stosunków pracy osób świadczących pracę na rzecz misji pojęcie pracodawcy należy wykładać zgodnie z regułami wykładni autonomicznej, która w dużym stopniu powinna odwoływać się do zwyczajów i umów międzynarodowych. Powoływanie się wyłącznie na prawo krajowe (kolizyjne i materialne) nie jest poprawne. W związku z tym, pracodawcą pracowników zatrudnionych w misji obcego państwa jest państwo. W szczególności, błędny jest pogląd, aby to ambasada, konsulat lub jakakolwiek misja była pracodawcą. Wprawdzie powoduje to wątpliwości interpretacyjne związane $\mathrm{z}$ wynikającą z polskiego prawa pracy zasadą, że pracodawcą nie jest państwo, lecz jego organy, jednak więcej korzyści płynie z modyfikacji tej reguły i dopuszczenia, aby wyjątkowo państwo obce było stroną stosunku pracy. Przedstawiciel państwa będzie podmiotem samodzielnie zatrudniającym osoby fizyczne w przypadku służby domowej.

4. Dla rozstrzygnięcia, czy w sprawie pracowniczej możliwe jest powoływanie się przez państwo na immunitet jurysdykcyjny, pomocne mogą być cztery metody. Pierwsza dotyczy oceny kontekstu lub umiejscowienia stosunku pracy. Druga sprowadza się do ustalenia statusu i obowiązków pracownika. Trzecia odnosi się do ustalenia terytorialnego powiązania pracownika i umowy o pracę z państwem forum. Wreszcie czwarta dotyczy analizy samego powództwa i ustalenia, czy środek ten nie spowoduje nadmiernego wkroczenia we władzę suwerennego państwa.

5. Art. 11 konwencji z 2004 r. oraz art. 5 konwencji bazylejskiej powinny być pomocniczo stosowane przez sądy polskie w celu ustalenia istnienia immunitetu państwa obcego. Nawet przy braku akceptacji dla poglądu, że ich treść odzwierciedla zwyczaj międzynarodowy, reguły z tych przepisów powinny stanowić podstawę dla praktyki orzeczniczej sądów polskich. 